\title{
MDM2 Gene
}

National Cancer Institute

\section{Source}

National Cancer Institute. MDM2 Gene. NCI Thesaurus. Code C18345.

This gene plays a role in several cellular processes related to cellular viability; including the cell cycle and apoptosis. 